\title{
Cytokine changes in the postoperative period
}

\author{
BY ALAN SHENKIN \\ Department of Clinical Chemistry, University of Liverpool, PO Box 147, Liverpool L69 3BX
}

Tissue injury stimulates a coordinated response of endocrine and cytokine factors, which mediate the metabolic response over the period until healing occurs (Lowry, 1992). The more severe the trauma, the greater are the associated metabolic changes (Kinney et al. 1970 ), and these in turn correlate with increased activity of the mediators (Wilmore, 1986). These changes are beneficial in the short term, mobilizing body substrates and activating the tissue defence mechanisms which reduce infection and promote repair. However, if the process continues for a prolonged period it leads to progressive depletion of the body cell mass with impaired immune competence, and an increased incidence of potentially serious complications. There has been much recent attention, therefore, in attempts to limit the magnitude of the rise in endocrine and cytokine mediators following trauma in the hope that this will improve long-term survival.

Operative trauma differs from accidental trauma in the use of anaesthesia with control of vital functions, and this tends to reduce the magnitude of the metabolic response to elective surgery (Kinney et al. 1970). Nonetheless, in the postoperative period patients show characteristic changes in acute-phase proteins, leukocytes, and depending on the extent of the surgery, increased energy expenditure and protein catabolism (Lowry, 1992). It seems likely that these features result mainly from the activation of the cytokine pathways, whereas changes in carbohydrate and fat metabolism are primarily due to catecholamine, adrenocortical and glucagon responses (Wilmore, 1986). Anorexia is a notable feature in traumatized patients, and it has been suggested that this is a further effect of cytokine activation (Tracey et al. 1988). Thus, cytokines may promote cachexia in at least two ways during severe illness; first by reducing nutritional intake, and second by increasing metabolic requirements (Billiau \& Matthys, 1992).

The cytokines most involved in these processes are the interleukins (IL) IL- $1 \alpha$, IL-1 $\beta$, IL-6 and tumour necrosis factor (TNF), and interferon $\gamma$. The main object of the present paper is to review some of the evidence for cytokine activation at this time, and the effect which this has in altering food intake.

\section{TISSUE SYNTHESIS AND RELEASE OF CYTOKINES}

Various tissues can elaborate cytokines following injury. Keratinocytes and fibroblasts damaged at the site of injury release IL-1 and IL-6, and the early recruitment of tissue macrophages leads to synthesis of a spectrum of cytokines including IL-1 and TNF (Dinarello, 1989). Circulating monocytes also are activated to produce increased IL-1, IL-6 and TNF (Cabie et al. 1992). Subsequently distant tissues also become activated, and there is evidence of Kupffer cell, brain cell, and other tissue macrophage activation (Dinarello, 1984).

\section{PLASMA CYTOKINES IN THE POSTOPERATIVE PERIOD}

A number of studies have examined cytokine changes following elective surgery, this being a particularly useful model since preoperative specimens can be obtained. 


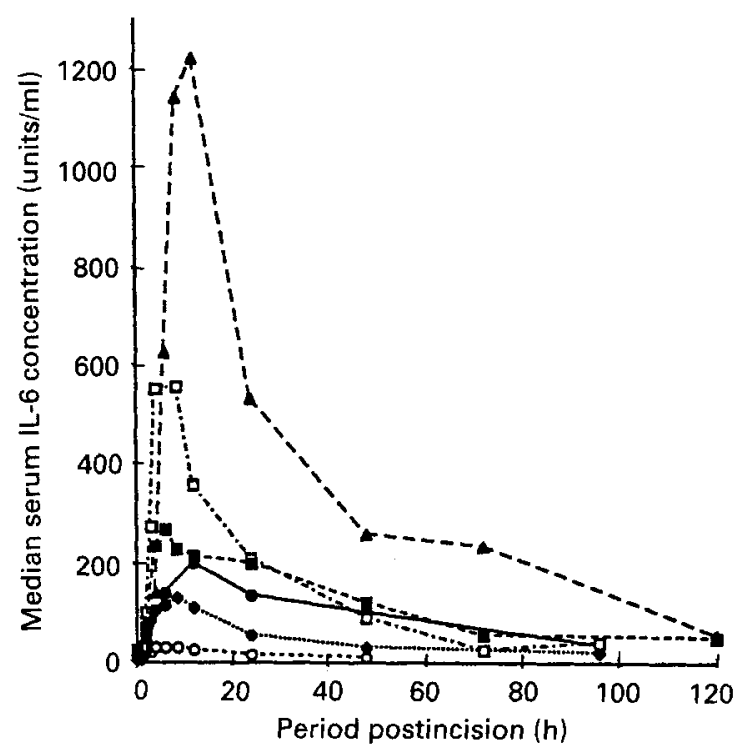

Fig. 1. Serum interleukin-6 (IL-6) response to elective surgery of varying severity: $(0)$, minor $(n 6) ;(\diamond)$,

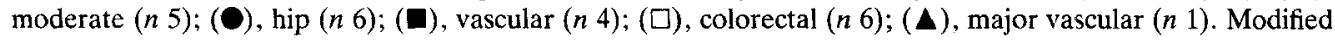
from Cruickshank et al. (1990b).

Although most studies have failed to show reproducible changes in plasma IL-1 (Cruickshank et al. 1990b), an early, short-lasting change has been observed using a sensitive immunoassay (Baigrie et al. 1992a). The peak IL-1 $\beta$ concentration of about 15 $\mathrm{pg} / \mathrm{ml}$ was observed at $2 \mathrm{~h}$ postincision in patients undergoing aortic aneurysm repair, but no elevation was detected in patients undergoing repair of inguinal hernia. There was no significant difference in the IL-1 $\beta$ response in patients who had an uncomplicated postoperative course in comparison with those who developed infectious or other complications. IL-1-receptor antagonist (IL-1 ra), a protein which inhibits IL-1 activity by binding to the receptor (Dinarello \& Thompson, 1991), may reflect activation and release of IL-1, and recent studies have demonstrated an early rise in plasma IL-1 ra postoperation, with a peak at about $6 \mathrm{~h}$ (Di Padova et al. 1991; Curtis et al. 1993).

Operative trauma induces consistent changes in plasma concentration of IL-6. The larger the operative procedure, the greater the plasma IL-6 response. Thus, Cruickshank et al. (1990b) demonstrated that a hernia repair induces only a small IL-6 response, cholecystectomy a greater response, and colorectal resection and aortic bifurcation graft the largest responses, peaking at 4-12 h (Fig. 1). Plasma IL-6 is also a sensitive early marker of postoperative infection, both in terms of the magnitude of the response (Damas et al. 1992) and its duration (Cruickshank et al. 1990a). The IL-6 response, in general, correlates with the magnitude of the subsequent acute-phase protein response as measured by C-reactive protein (CRP; Fig. 2). It is noteworthy that in a recent comparison of laparoscopic with open cholecystectomy (Jakeways et al. 1993), the laparoscopic procedure was associated with lower IL- 6 and CRP responses. These findings may be of special relevance with regard to the effects on appetite at this time. 


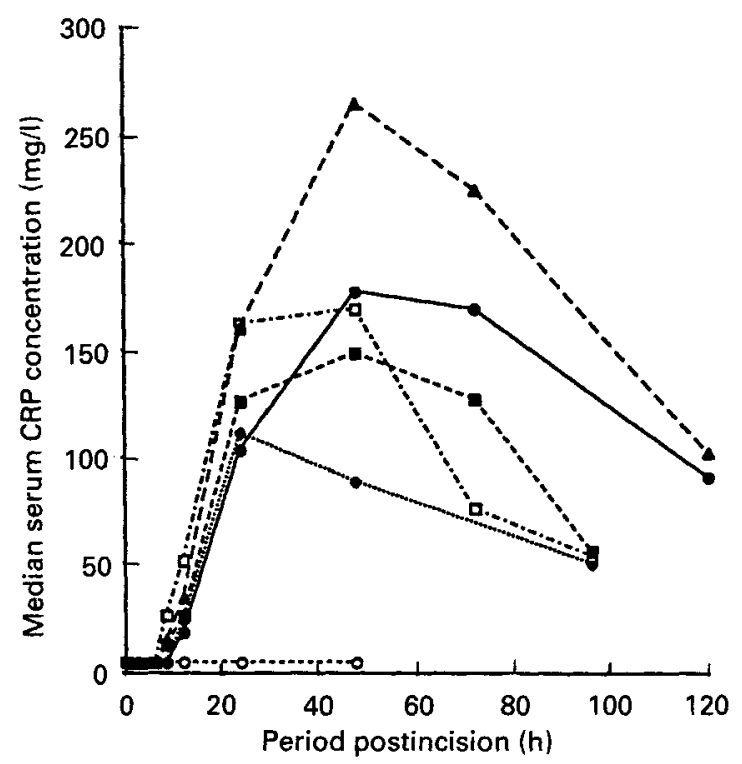

Fig. 2. Serum C-reactive protein (CRP) response to elective surgery of varying severity: $(O)$, minor $(n 6) ;(\diamond)$,

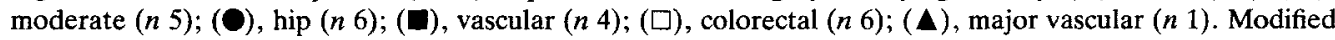
from Cruickshank et al. (1990b).

Interferon $\gamma$ was not detected in plasma in the period following major surgery (Baigrie et al. 1992a). TNF was only detected in one patient (of twenty) who developed systematic complications in the study of Baigrie et al. (1992a), and three of twenty-eight in the studies of Cruickshank et al. (1990b), only one of whom had a major septic complication. TNF has been detected during operation in some patients undergoing aortic surgery, and it has been suggested that this may be due to translocation of endotoxin through the gut wall as a result of intestinal ischaemia (Cabie et al. 1992).

Most studies of TNF have indicated some general difficulties in relation to plasma assays. First, its detection in plasma depends on the assay used, since different assays may detect only free TNF or TNF bound to soluble receptors or other plasma proteins (Engelberts et al. 1991). Second, TNF is only variably detected in patients with severe sepsis or burns, probably because TNF acts locally and may be released in a paracrine mode by monocytes and tissue macrophages (Debets et al. 1989; Marano et al. 1990). It may well be that TNF (and IL-1) is too potent a substance to circulate in a free form in plasma, and, hence, it would only be detected in plasma when there has been substantial overflow from tissue production and local binding proteins (Tracey et al. 1989). Consistent with this is the observation that high concentrations of TNF or IL-1 in plasma are associated with a poor progress (Girardin et al. 1988; Calandra et al. 1990).

TNF may appear in plasma in response to endotoxin. Michie et al. (1988) demonstrated that an endotoxin injection in healthy volunteers was associated with an increase in plasma TNF peaking at about $2 \mathrm{~h}$, which is earlier than would be expected for plasma IL-6. 


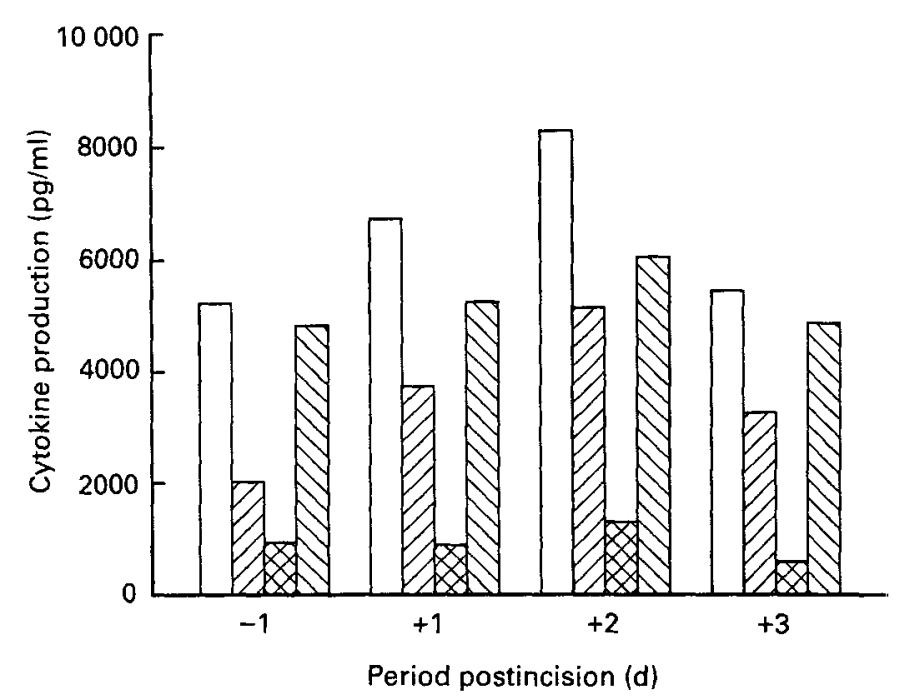

Fig. 3. In vitro cytokine release from monocytes stimulated with Staphylococcal toxin (TSST), from patients

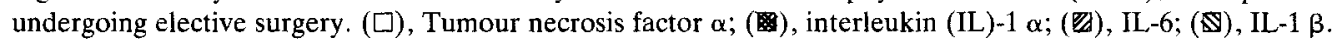
Modified from Cabie et al. (1992).

In these studies, interferon $\gamma$ and IL-1 $\beta$ were not increased by endotoxin administration.

A better marker of TNF activation postsurgery may be the measurement of soluble TNF receptors (sTNFRp55 and sTNFRp75), which are released as a result of TNF activation during endotoxaemia (Spinas et al. 1992). We have recently observed increased sTNFRp55 and sTNFRp75 activity in the postoperative period (Curtis et al. 1993), and increased TNF-receptor activity has been observed in HIV infection, another disease state associated with weight loss (Kalinkovich et al. 1992).

\section{INCREASED MONOCYTE ACTIVATION FOLLOWING SURGERY}

Peripheral blood monocytes collected from patients following surgery have been found to have enhanced ability to secrete cytokines. Monocytes stimulated with either endotoxin or Staphylococcal toxin, TSST-1, stimulate a greater amount of TNF $\alpha$, IL-6, IL-1 $\alpha$ and IL-1 $\beta$ by 2-3 d postoperation (Cabie et al. 1992; Fig. 3) and interferon $\gamma$ is also secreted in increased amounts (Baigrie et al. 1992b).

\section{EFFECTS OF NUTRITIONAL STATUS ON CYTOKINE CHANGES POSTOPERATION}

Malnutrition is associated with a reduction in the magnitude of many aspects of the response to injury or infection. Protein malnutrition causes a reduction in the fever response to bacterial infection in rabbits (Hoffman-Goetz \& Kluger, 1979) and reduced protein catabolism in rats (Cuthbertson \& Tilstone, 1968). Acute-phase protein synthesis is also reduced following turpentine injection in protein-depleted rats (Jennings et al. 1992) and in the postoperative period in patients with protein-energy depletion 
(Cruickshank et al. 1989). The reduction in plasma Fe induced by bacterial infection was also less marked in protein-depleted rabbits (Hoffman-Goetz \& Kluger, 1979). Recent studies have demonstrated no significant differences, however, in the postoperative fall in plasma $\mathrm{Fe}$ or plasma $\mathrm{Zn}$ in cachectic patients compared with well-nourished controls (G. Curtis and A. Shenkin, unpublished results).

In some studies it seems likely that the release of cytokines is reduced by malnutrition. Thus, in the studies of Keenan et al. (1982) intravenous feeding of malnourished patients led to the enhanced ability of leukocytes to release leukocyte endogenous mediator in response to endotoxin. On the other hand, studies in rats (Jennings et al. 1992) and man (Curtis et al. 1993) indicate that although the acute-phase protein production in response to an inflammatory or operative stimulus is reduced, the cytokine release, as measured by plasma IL-6, is not significantly altered by malnutrition. Whether this is also the case for tissue production and release of cytokines for paracrine activity remains to be established. At present, however, it seems more likely that severe malnutrition alters the effectiveness of cytokines in stimulating new protein synthesis, rather than the synthesis and release of the cytokines themselves.

The reproducibility of the IL-6 response to surgery is consistent with the observation that hepatocytes undergoing an acute-phase response require exogenous IL-6 and that IL-6, therefore, probably functions as an exocrine hormone in inflammation (Gauldie et al. 1990).

\section{EFFECT OF INCREASED CYTOKINE PRODUCTION ON FOOD INTAKE}

Injection of cytokines causes weight loss and a reduction in food intake. Michie et al. (1989) demonstrated that continuous TNF infusion in rats $(90 \mu \mathrm{g} / \mathrm{kg}$ per d) led to a marked reduction in food intake and $\mathrm{N}$ balance. Pair-fed animals infused with saline $(9 \mathrm{~g}$ $\mathrm{NaCl} / \mathrm{l}$ ) alone showed a similar effect on $\mathrm{N}$ balance, indicating that the impairment in $\mathrm{N}$ balance and the loss of weight were not the result of increased protein catabolism in the TNF-infused group, but rather was due to reduced food intake. It was noteworthy that, after a short period of weight loss, TNF infusion actually led to progressive weight gain as a result of marked fluid retention.

Similarly, mice which have undergone transduction with a TNF-secreting gene, so that they produce TNF constitutively in large amounts, become markedly cachectic (Oliff et al. 1989).

It seems that there is a need for continuous secretion or infusion of TNF in these animals to produce sustained anorexia and weight loss. Animals given TNF by daily bolus injections become tolerant of the effects (Fraker et al. 1988; Tracey et al. 1988). This observation has interesting implications for the anorexia of chronic inflammatory and neoplastic disease. Similarly, endotoxin injections and IL-1 infusions in rats lead to reduced food intake and cachexia (Fong et al. 1989; Uehara et al. 1989).

Interferon $\gamma$ has recently been shown to play a role in cachexia/anorexia. Nude mice inoculated with Chinese hamster ovary cells, which produce interferon $\gamma$ constitutively, rapidly become cachectic, and this can be prevented by passive immunization against interferon $\gamma$. Monoclonal antibodies to interferon $\gamma$ have also been shown to prevent cachexia in some animal tumour models (Billiau \& Matthys, 1992).

However, in disease in animals or man it seems unlikely that cachexia is due to the action of a single cytokine, since in the clinical situation activation of monocytes and macrophages will lead to increases in a 'cocktail' of cytokines (Fig. 3). 


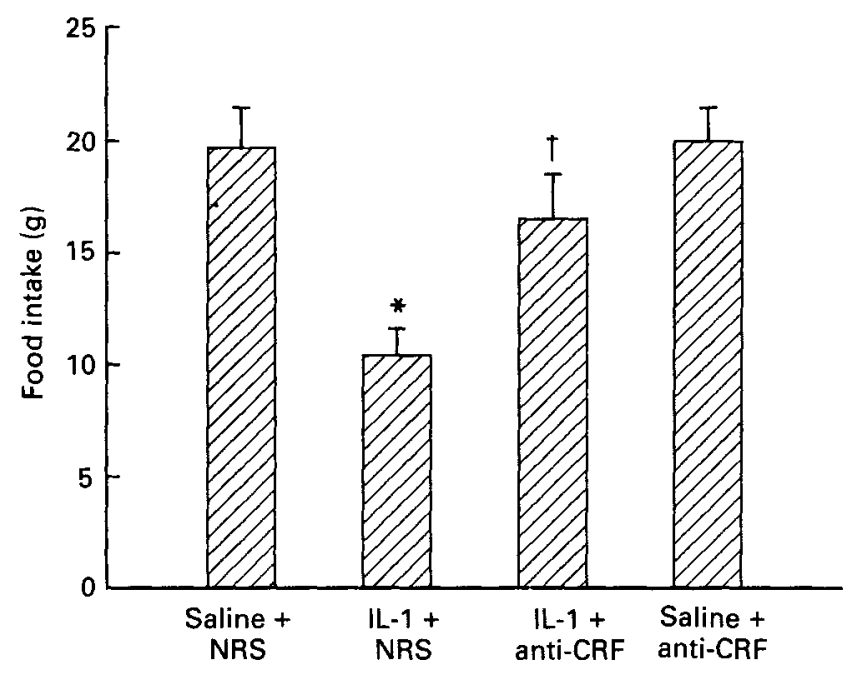

Fig. 4. Effect of intracerebroventricular injection of antiserum against corticotrophin-releasing factor (CRF) on interleukin-1 (IL-1)-induced suppression of food intake. Rabbits were preinjected with anti-CRF or normal rabbit serum (NRS), and IL-1 or saline $(9 \mathrm{~g} \mathrm{NaCl} / \mathrm{l})$ was injected intraperitoneally. Mean value was significantly different from that for saline + NRS: $* P<0 \cdot 01$. Mean value was significantly different from that for IL- $1+$ NRS: $† P<0.01$. Values are means with their standard errors represented by vertical bars. Adapted from Uehara et al. (1989).

\section{MECHANISM OF CYTOKINE EFFECT ON FOOD INTAKE}

Food intake is controlled by a variety of mechanisms, neurological, physiological and psychological. A large number of peptide mediators have been shown to affect food intake, and the cytokines are thought to be of particular importance (York, 1991). Direct injection of IL-1 or TNF into the hypothalamus of rats leads to a reduction in food intake (Rothwell, 1992). Whether this is the site of IL-1 or IL-6 synthesis in the brain, or whether IL-1 can enter the brain across the blood-brain barrier (currently thought to be unlikely) remains to be established. IL-1 $\beta$ has been found in high concentration in a number of areas of the brain, and specific cell types within the brain have been shown to synthesize cytokines (Van Dam et al. 1992).

A key mechanism for the effect of cytokines appears to be the release of corticotrophin-releasing factor (CRF) from the hypothalamus which in turn has a major role in causing a reduction in food intake (Berkenbosch et al. 1987; Sapolsky et al. 1987). Rothwell and colleagues (Rothwell, 1989) have demonstrated that the effects of IL-1 $\beta$ and IL- 6 on fever and thermogenesis can be blocked by inhibiting CRF activity. The effects of IL-1 in inhibiting food intake in mice have also been modified using CRF antibodies (Fig. 4; Uehara et al. 1989).

Thus, induction of CRF by cytokines may be an important factor in producing anorexia, and methods of reducing the CRF release may prove to be of some clinical benefit in improving appetite in those individuals who have a chronic increased cytokine production. For example, since prostaglandins appear to be part of the mechanism by which cytokines induce fever, modulation of prostaglandin activity, perhaps by use of 
specific cyclooxygenase inhibitors, may have an effect on CRF action and subsequently on food intake (Rothwell, 1992).

The role of CRF is of obvious importance in the anorexia following surgery, and it demonstrates the complexity of the interaction between the cytokine and the classical neuroendocrine system; the cytokines cause increased secretion of CRF, whereas increased release of glucocorticoids causes inhibition of CRF as part of the traditional negative feedback pathway.

\section{SUMMARY}

The trauma of elective surgery leads to the release of cytokines, many of which act primarily at local level having been released from tissue macrophages, circulating monocytes or other activated tissues. There is also a reproducible response in plasma IL-6, the magnitude of which relates to the magnitude of operative trauma. It seems likely that cytokines have an important role in mediating the anorexia associated with the postoperative period, and this may be associated with increased release of CRF from the hypothalamus. Further studies on the interrelationship between cytokine and neuroendocrine systems will lead to a greater understanding of the control of food intake following injury, and will permit the development of new strategies to improve the effectiveness of nutrition at this time.

\section{REFERENCES}

Baigrie, R. J., Lamont, P. M., Kwiatkowski, D., Dallman, M. J. \& Morris, P. J. (1992a). Systemic cytokine response after major surgery. British Journal of Surgery 79, 757-760.

Baigrie, R. J., Lewis, C. E., Lamont, P. M., Morris, P. J. \& McGee, J. O. D. (1992b). Effect of major surgery on the release of interferon gamma by peripheral blood mononuclear cells: an investigation at the single cell level using the reverse hemolytic plaque assay. Cytokine 4, 63-65.

Berkenbosch, F., Van Oers, J., del Rey, A., Tilders, F. \& Besedovsky, H. (1987). Corticotrophin releasing factor producing neurons in the rat - activation by interleukin $1 \beta$. Science 238, 524-528.

Billiau, A. \& Matthys, P. (1992). Interferon $\gamma$, more of a cachectin than tumour necrosis factor. Cytokine 4, 259-263.

Cabie, A., Fitting, C., Farkas, J.-C., Laurian, C., Cormier, J.-M., Carlet, J. \& Cavaillon, J.-M. (1992). Influence of surgery on in-vitro cytokine production by human monocytes. Cytokine 4, 576-580.

Calandra, T., Baumgartner, J.-D., Grau, G. E., Wu, M.-M., Lambert, P.-H., Schellekens, J., Verhoef, J., Glauser, M. P. \& the Swiss-Dutch IS Immunoglobulin Study Group (1990). Prognostic value of tumour necrosis factor/cachectin, interleukin 1 , interferon $\alpha$, and interferon $\gamma$ in the serum of patients with septic shock. Journal of Infectious Disease 161, 982-987.

Cruickshank, A. M., Burns, H. J. G. \& Shenkin, A. (1990a). Serum IL-6 as a prognostic indicator in surgical patients. Clinical Nutrition 9, Suppl., 4..

Cruickshank, A. M., Fraser, W. D., Burns, H. J. G., Van Damme, J. \& Shenkin, A. (1990b). Response of serum interleukin 6 in patients undergoing elective surgery of varying severity. Clinical Science 79, 161-165.

Cruickshank, A. M., Hansell, D. T., Burns, H. J. G. \& Shenkin, A. (1989). Effect of nutritional status on acute phase protein response to elective surgery. British Journal of Surgery 76, 165-168.

Curtis, G. E., McAtear, C., Formela, L., Walsh, A. \& Shenkin, A. (1993). The effect of nutritional status on interleukin-6 response to elective surgery. Proceedings of the Nutrition Society 52, 232A.

Cuthbertson, D. P. \& Tilstone, W. J. (1968). Nutrition of the injured. American Journal of Clinical Nutrition 21, 911-922.

Damas, P., Ledoux, D., Nys, M., Vrindts, Y., de Groote, D. \& Franchimont, P. (1992). Cytokine serum level during severe sepsis in humans: IL-6 as a marker of severity. Annals of Surgery 215, 356-362.

Debets, J. M. H., Kampmeijer, R., Van der Linden, M., Buurman, W. A. \& Van der Linden, C. J. (1989). Plasma tumour necrosis factor and mortality in critically ill septic patients. Critical Care Medicine 17, $489-494$. 
Dinarello, C. A. (1984). Interleukin 1. Review of Infectious Diseases 6, 51-95.

Dinarello, C. A. (1989). Interleukin 1 and its related cytokines. In Cytokines, vol. 1, pp. 105-154 [C. Sorg, editor]. Basel: Karger.

Dinarello, C. A. \& Thompson, R. C. (1991). Blocking IL-1: interleukin 1 receptor antagonist in vivo and in vitro. Immunology Today 12, 404-410.

Di Padova, F., Pozzi, C., Tondre, M. J. \& Tritapepe, R. (1991). Selective and early increase of IL-1 inhibitors, IL-6 and cortisol after elective surgery. Clinical and Experimental Immunology 85, 137-142.

Engleberts, I., Stephens, S., Srancot, G. J. M., Van der Linden, C. J. \& Buurman, W. A. (1991). Evidence for different effects of soluble TNF receptors on various TNF measurements in human biological fluids. Lancet 338, 515-516.

Fong, Y., Moldawer, L. L., Marano, M., Wei, H., Barber, A., Manogue, K., Tracey, K. J., Kuo, G., Fischman, D. A., Cerami, A. \& Lowry, S. F. (1989). Cachectin/TNF or IL1 $\alpha$ induces cachexia with redistribution of body proteins. American Journal of Physiology 256, R659-R665.

Fraker, D. L., Stovroff, M. C., Merino, M. \& Norton, J. A. (1988). Tolerance to tumour necrosis factor in rats and the relationship to endotoxin tolerance and toxicity. Journal of Experimental Medicine 168, 95-105.

Gauldie, J., Northemann, W. \& Fey, G. H. (1990). IL-6 functions as an exocrine hormone in inflammation. Hepatocytes undergoing acute phase responses require exogenous IL-6. Journal of Immunology 144, 3804-3808.

Girardin, E., Gran, G. E., Dayer, J.-M., Roux-Lombard, P. \& Lambet, P.-H. (1988). Tumour necrosis factor and interleukin-1 in the serum of children with severe infectious purpura. New England Journal of Medicine $319,397-400$.

Hoffman-Goetz, L. \& Kluger, M. J. (1979). Protein deprivation: its effect on fever and plasma iron during bacterial infection in rabbits. Journal of Physiology 295, 419-430.

Jakeways, M. S. R., Mitchell, V., Hashim, I. A., Chadwick, S. J. D., Shenkin, A., Green, C. J. \& Carli, F. (1994). Metabolic and inflammatory responses after open or laparoscopic cholecystectomy. British Journal of Surgery $\mathbf{8 1}, 127-131$.

Jennings, G., Cruickshank, A. M., Shenkin, A., Wight, D. G. \& Elia, M. (1992). Effect of aseptic abscesses in protein deficient rats on the relationship between interleukin- 6 and the acute phase protein, $\alpha_{2}$ macroglobulin. Clinical Science 83, 731-735.

Kalinkovich, A., Engelmann, H., Harpaz, N., Burstein, R., Barak, V., Kalickman, I., Wallach, D. \& Bentwich, Z. (1992). Elevated serum levels of soluble tumour necrosis factor receptors (sTNF-R) in patients with HIV infection. Clinical and Experimental Immunology 89, 351-355.

Keenan, R. A., Moldawer, L. L., Yang, R. D., Kawamura, I., Blackburn, G. L. \& Bistrian, B. (1982). An altered response by peripheral leucocytes to synthesise or release leucocyte endogenous mediator in critically ill protein-malnourished patients. Journal of Laboratory and Clinical Medicine 100, 844-857.

Kinney, J. M., Long, C. L. \& Duke, J. H. (1970). Carbohydrate and nitrogen metabolism after injury. Ciba Foundation Symposium. Energy Metabolism in Trauma, pp. 103-126 [R. Porter and J. Knight, editors]. London: Churchill.

Lowry, S. F. (1992). Modulating the metabolic response to injury and infection. Proceedings of the Nutrition Society 51, 267-277.

Marano, M. A., Fong, Y., Moldawer, L. L., Wei, H., Calvano, S. E., Tracey, K. J., Barie, P. S., Manogue, K., Cerami, A., Shires, G. T. \& Lowry, S. F. (1990). Serum cachectin, tumour necrosis factor in critically ill patients with burns, correlates with infection and mortality. Surgery, Gynaecology and Obstetrics 170, $32-38$.

Michie, H. R., Manogue, K. R., Spriggs, D. R., Revhaug, A., O'Dwyer, S., Dinarello, C. A., Cerami, A., Wolff, S. M. \& Wilmore, D. W. (1988). Detection of circulating tumour necrosis factor after endotoxin administration. New England Journal of Medicine 318, 1481-1486.

Michie, H. R., Sherman, M. L., Spriggs, D. R., Rounds, J., Christie, M. \& Wilmore, D. W. (1989). Chronic TNF infusion causes anorexia but not accelerated nitrogen loss. Annals of Surgery 209, 19-24.

Oliff, A., Defeo-Jones, D., Boyer, M., Martinez, D., Kiefer, D., Vuocolo, G., Wolfe, A. \& Socher, S. H. (1989). Tumours secreting human TNF cachectin induce cachexia in mice. Cell 50, 555-563.

Rothwell, N. J. (1989). CRF is involved in the pyrogenic and thermogenic effects of Interleukin-1 $\beta$ in the rat. American Journal of Physiology 256, E111-E115.

Rothwell, N. J. (1992). Autonomic and central control of thermogenesis. In Obesity and Cachexia, pp. 13-32 [N. J. Rothwell and M. J. Stock, editors]. Chichester: John Wiley \& Sons.

Sapolsky, R. M., Rivier, C., Yamamoto, G., Plotsky, G. \& Vale, W. (1987). Interleukin-1 stimulates the secretion of hypothalamic corticotrophin releasing factor. Science 238, 522-524. 
Spinas, G. A., Keller, U. \& Brockhaus, M. (1992). Release of soluble receptors for tumour necrosis factor (TNF) in relation to circulating TNF during experimental endotoxaemia. Journal of Clinical Investigation 90, 533-536.

Tracey, K. J., Vlassara, H. \& Cerami, A. (1989). Cachectin/tumour necrosis factor. Lancet i, 1122-1125.

Tracey, K. J., Wei, H., Manogue, K. R., Fong, Y., Hesse, D. G., Nguyen, H., Kuo, G. C., Beutler, B., Cotran, R. S., Cerami, A. \& Lowry, S. F. (1988). Cachectin/tumour necrosis factor induces cachexia, anaemia, and inflammation. Journal of Experimental Medicine 167, 1211-1227.

Uehara, A., Sekiya, C., Takasugi, Y., Namiki, M. \& Arimura, A. (1989). Anorexia induced by interleukin 1: involvement of corticotrophin releasing factor. American Journal of Physiology 257, R613-R617.

Van Dam, A. M., Brouns, M., Louisse, S. \& Berkenbosch, F. (1992). Appearance of interleukin-1 in macrophages and in ramified microglia in the brain of endotoxin treated rats: a pathway for the induction of non-specific symptoms of sickness? Brain Research 588, 291-296.

Wilmore, D. W. (1986). Are the metabolic alterations associated with critical illness related to the hormonal environment? Clinical Nutrition 5, 9-19.

York, D. A. (1991). Neuroendocrine and metabolic derangements in animal models of obesity. In Obesity and Cachexia, pp. 103-118 [N. J. Rothwell and M. J. Stock, editors]. Chichester: John Wiley \& Sons. 